\title{
Operating value and economic efficiency of Large White breed sows
}

\author{
V. Khalak', B. Gutyj ${ }^{2}$, O. Bordun ${ }^{3}$, A. Horchanok ${ }^{4}$, M. Ilchenko ${ }^{5}$, S. Smyslov5, \\ L. Lytvyshchenko ${ }^{4}$, L. Kuzmenko ${ }^{6}$ \\ ${ }^{1}$ State Institution Institute of Grain Crops of NAAS, Dnipro, Ukraine \\ ${ }^{2}$ Stepan Gzhytskyi National University of Veterinary Medicine and Biotechnologies Lviv, Ukraine \\ ${ }^{3}$ Institute of Agriculture of Northern East of National Academy of Agrarian Sciences of Ukraine, \\ Sumy, Ukraine \\ ${ }^{4}$ Dnipro State University of Agriculture and Economics, Dnipro, Ukraine \\ ${ }^{5}$ Institute of Pig Breeding and Agroindustrial Production, Poltava, Ukraine \\ ${ }^{6}$ Poltava State Agrarian Academy, Poltava, Ukraine \\ *Corresponding author E-mail: v16kh91@gmail.com, bvh@ukr.net \\ Received: 13.07.2020. Accepted 26.08.2020
}

\begin{abstract}
The article deals with the reproductive qualities of Large White breed sows of Hungarian origin and their operational value. We also determined they economic efficiency. The experimental part of the research was conducted in agricultural formations of Dnipro region (AALLC "Druzhba-Kaznachejivka", Ltd. "Vidrodzhennja") and livestock laboratories of the State establishment Institute of Grain Crops NAAS. Evaluation of sows on the main indicators of the level of adaptation and reproductive qualities was performed taking into account the following quantitative characteristics: life expectancy, months, duration of breeding use, farrowing was obtained, total piglets were obtained, heads, live piglets were obtained, heads, fertility of heads, nest masst at the time of weaning at the age of 28 days $(\mathrm{kg})$, preservation (\%), duration of between farrowing period, days, number of unproductive days per farrowing. It is defined that sows of Large White breed of the controlled herd on the main indicators of reproductive qualities (fertility, head; nest mass at the time of weaning at the age of 28 days, kg) meet the minimum requirements of class I and elite class. A significant difference between the groups of animals of the categories "high operational value" and "low operational value" was defined by indicators "life expectancy, months" (29.9 months, td = 13.71), "duration of breeding use, months" (29.6 months, td = 14.50), "farrowings were obtained" (5.7 farrowings, td = 14.50), "total piglets were obtained, heads" (70.5, heads, $t d=13.85)$, "obtained live piglets, heads" (67.7 heads, td = 20.83), "fertility, heads " (3.3 heads, td $=10.31)$, nest mass at the time of weaning at the age of 28 days $(6.5 \mathrm{~kg}, \mathrm{td}=2.55)$. Coefficients of phenotypic consolidation of signs of reproductive qualities in sows of different operational value ranged from -0.785 to +0.856 . The maximum supplement in additional products on the indicator "nest mass at the time of weaning at the age of 28 days, kg" was obtained from sows of the category "high operational value" - 6.03\%.
\end{abstract}

Keywords: sow, breed, reproductive qualities, life expectancy, operational value, phenotypic consolidation coefficient, economic efficiency, variability.

\section{Introduction}

The experience of specialists of agricultural formations, as well as researches of domestic and foreign scientists testify that the current issues of development of the pig industry, along with improving the conditions of feeding and keeping animals of different production groups, there is the introduction of objective methods for assessing the breeding value of repair young stock, sows and breeding boars of the main herd (DNA markers, BLUP method, evaluative and selective indices), selection of highly productive animals and their intensive use (Mikhaylova, 2017; Kabanov, 2009; Voloshchuk, 2014; Berezovsky \& Vashchenko, 2015; Hryshyna \& Fesenko, 2015; Rybalko, 2015; Gutyj et al., 2017; Kozyr et al., 2019; Martyshuk et al., 2020; Khalak et al., 2020). In connection with the intensive import of pigs of foreign selection to Ukraine, important factors in the formation of a highly productive herd of pigs are the research of the level of their adaptation and operational value. This is confirmed by scientific developments of domestic and foreign scientists (Bazhov \& Komlatskiy, 1989; Herasymov et al., 2003; Kodak, 2010; Usenko et al., 2019). 
The purpose of the work is to investigate the reproductive qualities of sows of Large White breed of different operational value, to calculate the coefficients of phenotypic consolidation of this group of signs and the economic efficiency of research results. To achieve this goal, the following tasks were provided:

- on the basis of data of primary zootechnical documentation and results of own researches to give the characteristic of indicators of reproductive qualities of sows of Large White breed of the controlled herd;

- to determine the operational value of sows;

- to calculate the coefficients of phenotypic consolidation of signs of reproductive qualities of sows of different operational value and economic efficiency of research results.

\section{Material and Methods}

The research was conducted in terms of breeding sires for breeding Large White pigs AALLC "Druzhba-Kaznachejivka" Dnipro region and the laboratory of animal husbandry of the State establishment Institute of Grain Crops NAAS.

The evaluation of sows of Large White breed on the main indicators of the level of adaptation and reproductive qualities was carried out taking into account the following quantitative characteristics: life expectancy, months, duration of breeding use, farrowings were obtained, total piglets were obtained, heads, live piglets were obtained, heads, fertility, heads, nest mass at the time of weaning at the age of 28 days $(\mathrm{kg})$, preservation (\%), duration of between farrowing period, days, number of unproductive days per farrowing.

The operational value of sows of Large White breed of the controlled herd was determined by the method (Koryazhnov, 1985) (Table 1).

Table 1. Rating scale of the operational value of sows

\begin{tabular}{lcccc}
\hline $\begin{array}{c}\text { The level of } \\
\text { operational value }\end{array}$ & \multicolumn{2}{c}{ Operating value per farrowed sow } & \multicolumn{2}{c}{ Operating value per inseminated sow } \\
& $E_{1}$ (total piglets) & $E_{1}$ (including viable) & E2 (total piglets) & E2 (including viable) \\
\hline Low & $\leq 25$ & $\leq 20$ & $\leq 25$ & $\leq 15$ \\
Average & $26-40$ & $21-30$ & $21-44$ & $16-34$ \\
High & $\geq 50$ & $\geq 40$ & $\geq 45$ & $\geq 35$ \\
\hline
\end{tabular}

Selection index of sow reproductive qualities (SIRQS)(1), coefficients of phenotypic consolidation of quantitative signs of sows $\left(K_{1}, K_{2}\right)(2,3)$ and economic efficiency of research results $(4)$ were calculated by the formulas:

$$
\text { SIRQS }=6 \times X_{1}+9.34 \times\left(X_{2} / X_{3}\right)
$$

where: SIRQS - selection index of reproductive qualities of sows, score, $X_{1}$ - fertility, heads.; $X_{2}$ - nest mass of piglets at weaning, $\mathrm{kg} ; \mathrm{X}_{3}$ - age at the time of weaning, days (Tserenyuk et al., 2010);

$$
\begin{aligned}
& K_{1}=1-\frac{\sigma_{2}}{\sigma_{3}} \\
& K_{2}=1-\frac{C v_{2}}{C v_{3}}
\end{aligned}
$$

where: $\sigma_{2}$ and $c_{v_{2}}-$ an average quadratic deviation and coefficient of variability of signs in the group, $\sigma_{3}$ and $c_{v}-$ an average quadratic deviation and coefficient of variability in animals of the general population (Polupan, 1996);

$$
E=P P \times \frac{A A P \times A A}{100} \times C C \times N A
$$

where: $\mathrm{E}$ - cost of additional products, UAH; PP - purchase price per unit of output, in accordance with existing prices operating in Ukraine; AAP - average productivity of animals; AA - the average allowance of the main product (\%), which is expressed as a percentage per 1 head when using a new and improved selection achievement compared to the productivity of animals of basic use; CC - constant coefficient of reduction of the result, which is associated with additional costs for profitable products (0.75); $\mathrm{NA}$ - the number of livestock of new or improved breeding achievement, heads.

Biometric processing of the obtained research results was performed according to the method (Lakin, 1990).

\section{Results and discussion}

It is established that the life expectancy of sows of the main herd is $43.9 \pm 1.95$ mic. (lim $=21.7-87.0 ; \mathrm{CV}=35.34 \%$ ), duration of breeding use -32.6 \pm 1.92 months ( $\mathrm{lim}=9.6-71.9 ; \mathrm{CV}=46.89 \%)$, farrowings were obtained $-6.0 \pm 0.35(\mathrm{lim}=2-12 ; \mathrm{Cv}=47.18 \%)$, piglets of all $-65.5 \pm 4.35$ heads (lim = 8-145 heads; Cv $=52.79 \%)$, got live piglets $-62.2 \pm 4.12$ heads (lim = 7-135 heads; Cv = $53.53 \%$ ), fertility $-10.1 \pm 0.20$ heads (lim = 3-13 heads; $C v=15.90 \%)$, nest mass at the time of weaning at the age of 28 days $77.0 \pm 1.00 \mathrm{~kg}$. (lim=54,1-95,1 kg; Cv = 10.37\%), preservation $-95.0 \pm 0.75 \%$ (lim $=79-100 \%$ ), duration between the farrowing period - 175.5 \pm 3.92 days ( $\lim =147-279$ days; $C v=17.72 \%)$, the number of unproductive days per farrowing $-27.0 \pm 2.87$ days $(\lim =3-$ 98 days; $C v=84.47 \%$ ). Breeding index of reproductive qualities of sows (SIRQS) ranges from 43.46 to 101.55 points. 
The number of sows from which $84-135$ live piglets were obtained during the breeding period is $29.04 \%, 42-81$ heads. $-43.54 \%$, 7-39 heads. - $27.42 \%$.

The levels of adaptation and reproductive qualities of various operational value are given in Table 2.

Table 2. Indicators of life expectancy, breeding use, level of adaptation and reproductive qualities of sows of different operational value

\begin{tabular}{|c|c|c|c|c|}
\hline Indicators, units of measurement & $\begin{array}{l}\text { Biometric } \\
\text { indicator }\end{array}$ & \multicolumn{3}{|c|}{ Operational value } \\
\hline \multirow{4}{*}{ Life expectancy, months } & $\mathrm{n}$ & 37 & 19 & 7 \\
\hline & $\overline{\mathrm{X}} \pm S \bar{x}$ & $53.9 \pm 1.97$ & $31.8 \pm 1.17$ & $24.0 \pm 0.94$ \\
\hline & $\sigma \pm S \sigma$ & $12.01 \pm 1.396$ & $5.11 \pm 0.829$ & $2,49 \pm 0,665$ \\
\hline & $\mathrm{Cv} \pm \mathrm{S} c \mathrm{v}, \%$ & $22.28 \pm 2.590$ & $16.07 \pm 2.608$ & $10.37 \pm 2.772$ \\
\hline \multirow{3}{*}{ Duration of breeding use, months } & $\overline{\mathrm{X}} \pm S \bar{x}$ & $42.7 \pm 1.92$ & $20.3 \pm 0.92$ & $13.1 \pm 0.70$ \\
\hline & $\sigma \pm S \sigma$ & $11.69 \pm 1.359$ & $4.02 \pm 0.652$ & $1.86 \pm 0.497$ \\
\hline & $\mathrm{Cv} \pm \mathrm{S}_{\mathrm{Cv}}, \%$ & $27.37 \pm 3.182$ & $19.80 \pm 3.214$ & $14.19 \pm 3.794$ \\
\hline \multirow{3}{*}{ Obtained farrowings } & $\bar{X} \pm S \bar{x}$ & $7.9 \pm 0.34$ & $3.7 \pm 0.18$ & $2,2 \pm 0,18$ \\
\hline & $\sigma \pm S \sigma$ & $2.09 \pm 0.243$ & $0.80 \pm 0.129$ & $0.48 \pm 0.128$ \\
\hline & $\mathrm{Cv} \pm \mathrm{S}_{\mathrm{cv},} \%$ & $26.45 \pm 3.086$ & $21.62 \pm 3.509$ & $21.81 \pm 5.831$ \\
\hline \multirow{3}{*}{ Obtained total piglets, heads } & $\overline{\mathrm{X}} \pm S \bar{x}$ & $88.2 \pm 4.30$ & $39.0 \pm 1.55$ & $17.7 \pm 2.73$ \\
\hline & $\sigma \pm \mathrm{S} \sigma$ & $26.17 \pm 3.043$ & $6.79 \pm 1.102$ & $7.22 \pm 1.930$ \\
\hline & $\mathrm{Cv} \pm \mathrm{S}_{\mathrm{cv}}, \%$ & $29.67 \pm 3.450$ & $17.41 \pm 2.826$ & $40.79 \pm 10.906$ \\
\hline \multirow{3}{*}{ Obtained live piglets, heads } & $\overline{\mathrm{X}} \pm S \bar{x}$ & $83.9 \pm 2.00$ & $37.5 \pm 1.72$ & $16.2 \pm 2.57$ \\
\hline & $\sigma \pm S \sigma$ & $24.05 \pm 2.796$ & $7.53 \pm 1.222$ & $6.82 \pm 1.823$ \\
\hline & $\mathrm{Cv} \pm \mathrm{S}_{\mathrm{cv}}, \%$ & $28.67 \pm 3.337$ & $20.08 \pm 3.259$ & $42.09 \pm 11.254$ \\
\hline \multirow{3}{*}{ Fertility, heads } & $\overline{\mathrm{X}} \pm S \bar{x}$ & $10.6 \pm 0.14$ & $10.1 \pm 0.21$ & $7.3 \pm 0.29$ \\
\hline & $\sigma \pm S \sigma$ & $0.89 \pm 0.103$ & $0.94 \pm 0.152$ & $1.22 \pm 0.700$ \\
\hline & $\mathrm{Cv} \pm \mathrm{S}_{\mathrm{cv}}, \%$ & $8.39 \pm 0.975$ & $9.30 \pm 1.509$ & $16.71 \pm 4.467$ \\
\hline \multirow{3}{*}{$\begin{array}{l}\text { The mass of the nest at the time of } \\
\text { weaning at the age of } 28 \text { days, } \mathrm{kg} \text {. }\end{array}$} & $\overline{\mathrm{X}} \pm S \bar{x}$ & $77.9 \pm 1.34$ & $75.5 \pm 1.89$ & $71.4 \pm 2.17$ \\
\hline & $\sigma \pm \mathrm{S} \sigma$ & $8.18 \pm 0.951$ & $8.23 \pm 1.336$ & $5.74 \pm 1.534$ \\
\hline & $\mathrm{Cv} \pm \mathrm{S} c \mathrm{v}, \%$ & $10.50 \pm 1.220$ & $10.90 \pm 1.769$ & $8.03 \pm 2.147$ \\
\hline \multirow[t]{2}{*}{ Preservation, \% } & $\overline{\mathrm{X}} \pm S \bar{x}$ & $94.0 \pm 1.00$ & $95.6 \pm 1.40$ & $99.2 \pm 0.80$ \\
\hline & $\lim$ & 75.67-101.55 & $73.56-99.33$ & $43.46-84.10$ \\
\hline \multirow{3}{*}{$\begin{array}{l}\text { Selection index of sow reproductive } \\
\text { qualities (SIRQS), points }\end{array}$} & $\overline{\mathrm{X}} \pm S \bar{x}$ & $88.95 \pm 0.985$ & $83.13 \pm 2.011$ & $65.12 \pm 2.256$ \\
\hline & $\sigma \pm S \sigma$ & $6,60 \pm 0,764$ & $6.96 \pm 1.129$ & $7.77 \pm 2.077$ \\
\hline & $\mathrm{Cv} \pm \mathrm{S}_{\mathrm{cv}}, \%$ & $7.41 \pm 0.861$ & $8.37 \pm 1.358$ & $11.93 \pm 3.189$ \\
\hline \multirow{3}{*}{$\begin{array}{l}\text { Duration between the farrowing period, } \\
\text { days }\end{array}$} & $\overline{\mathrm{X}} \pm S \bar{x}$ & $167.8 \pm 3.30$ & $175.0 \pm 5.23$ & $217.1 \pm 22.78$ \\
\hline & $\sigma \pm S \sigma$ & $20.07 \pm 2.333$ & $22.80 \pm 3.701$ & $60.27 \pm 16.114$ \\
\hline & $\mathrm{Cv} \pm \mathrm{Scv}_{1} \%$ & $11.96 \pm 1.390$ & $13.02 \pm 2.113$ & $27.76 \pm 7.422$ \\
\hline \multirow{3}{*}{$\begin{array}{l}\text { Number of unproductive days per } \\
\text { farrowing, days }\end{array}$} & $\overline{\mathrm{X}} \pm S \bar{x}$ & $23.1 \pm 3.36$ & $26.9 \pm 3.88$ & $47.8 \pm 14.17$ \\
\hline & $\sigma \pm S \sigma$ & $20.47 \pm 2.380$ & $16.92 \pm 2.746$ & $37.49 \pm 10.024$ \\
\hline & $\mathrm{Cv}_{ \pm} \mathrm{S}_{\mathrm{Cv}}, \%$ & $88.61 \pm 10.303$ & $62.89 \pm 10.209$ & $78.43 \pm 20.970$ \\
\hline
\end{tabular}

We found that sows of the category "high operational value" dominated their peers of the opposite class "low operational value" in terms of life expectancy by 29.9 months. $(\mathrm{td}=13.71, \mathrm{P}<0.001)$, duration of breeding use $-29.6 \mathrm{months}$ (td = 14.50, $\mathrm{P}<0.001$ ). The difference between the animals of these groups on the indicators of "farrowings were obtained" is 5.7 of farrowings (td = $14.50, \mathrm{P}<0.001$ ), "obtained piglets in total, heads" - 70.5 heads (td $=13.85, \mathrm{P}<0.001$ ), "obtained live piglets, heads" - 67.7 heads $(\mathrm{td}=20.83, \mathrm{P}<0.001)$, "fertility, heads" - 3.3 heads $(\mathrm{td}=10.31, \mathrm{P}<0.001)$, the mass of the nest at the time of weaning at the age of 28 days $-6.5 \mathrm{~kg}$. ( $\mathrm{td}=2.55, \mathrm{P}<0.05)$, "selection index of reproductive qualities of sows (SIRQS), points" -23.83 points $(\mathrm{td}=$ 9.68, $\mathrm{P}<0.001)$.

Maximum indicators "preservation, \%", "duration of between farrowing period, days" and "number of unproductive days per farrowing" - 99.2 $\pm 0.80 \%, 217.1 \pm 22.78$ and $27.0 \pm 2.87$ days, respectively, was found in sows of the category "low operational value". 
The results of the calculation of the coefficients of phenotypic consolidation of signs of reproductive qualities of sows of different operational value are given in table 3.

Table 3. Coefficients of phenotypic consolidation of signs of reproductive qualities of sows of different operational value

\begin{tabular}{lcccc}
\hline Indicators, units of measurement & $\begin{array}{c}\text { Coefficients of } \\
\text { phenotypic } \\
\text { consolidation }\end{array}$ & high & $\begin{array}{c}\text { Operational value } \\
\text { average }\end{array}$ & low \\
\hline obtained farrowings & $\mathrm{n}$ & 33 & 104 & 36 \\
& $\mathrm{~K}_{1}$ & 0,159 & 0,725 & 0,856 \\
obtained piglets total, heads & $\mathrm{K}_{2}$ & 0,254 & 0,495 & 0,593 \\
& $\mathrm{~K}_{1}$ & 0,161 & 0,836 & 0,794 \\
obtained live piglets, heads & $\mathrm{K}_{2}$ & 0,310 & 0,678 & 0,176 \\
fertility, heads & $\mathrm{K}_{1}$ & 0,179 & 0,805 & 0,811 \\
nest mass at the time of weaning at the age & $\mathrm{K}_{2}$ & 0,327 & 0,612 & 0,197 \\
of 28 days, $\mathrm{kg}$ & $\mathrm{K}_{1}$ & 0,426 & 0,413 & $-0,785$ \\
& $\mathrm{~K}_{2}$ & 0,456 & 0,394 & $-0,998$ \\
& $\mathrm{~K}_{1}$ & 0,047 & $-0,226$ & 0,519 \\
& $\mathrm{~K}_{2}$ & 0,061 & $-0,246$ & 0,484 \\
\hline
\end{tabular}

Coefficients of phenotypic consolidation of signs of reproductive qualities in sows of different operational value ranged from 0.785 to +0.856 . The maximum values of the coefficient $\mathrm{K}_{1}$ were set on the indicator "obtained farrowings" and "obtained live piglets, heads" in sows of the category "low operational value" - +0.856 and +0.811 , respectively. The $K_{2}$ coefficient in sows of different operating ranges ranged from -0.998 to +0.678 .

The results of the calculation of the economic efficiency of the use of sows of different operational value are shown in table 4.

Table 4. Economic efficiency of research results

\begin{tabular}{|c|c|c|c|c|}
\hline $\begin{array}{l}\text { Group } \\
\text { (operational } \\
\text { value) }\end{array}$ & $n$ & $\begin{array}{l}\text { The mass of the nest at } \\
\text { the time of weaning at } \\
\text { the age of } 28 \text { days, } \mathrm{kg}\end{array}$ & $\begin{array}{l}\text { Addition of additional } \\
\text { products, } \%\end{array}$ & $\begin{array}{c}\text { Cost of additional } \\
\text { products, UAH/head * }\end{array}$ \\
\hline $\begin{array}{l}\text { The total } \\
\text { sample }\end{array}$ & 63 & $73.2 \pm 1.00$ & - & - \\
\hline low & 7 & $71.4 \pm 2.17$ & -2.45 & -60.93 \\
\hline average & 19 & $75.5 \pm 1.89$ & +3.04 & +75.60 \\
\hline high & 37 & $77.9 \pm 1.34$ & +6.03 & +149.96 \\
\hline
\end{tabular}

Note: * the selling price of young pigs on the date of the research was UAH 45.3. per $1 \mathrm{~kg}$ of live mass

We found that the maximum increase in additional products on the indicator "nest mass at the time of weaning at the age of

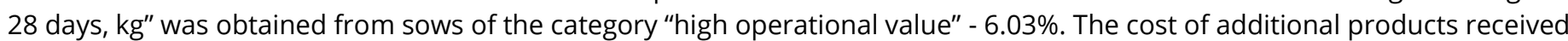
from animals of this group is $+149.96 \mathrm{UAH} /$ heads, provided that the sale price of young pigs to processing enterprises of the region at the time of the research is $45.3 \mathrm{UAH} / \mathrm{kg}$.

\section{Conclusions}

The results of the researches show that sows of Large White breed of controlled herd for fertility (heads) and the mass of the nest at the time of weaning at the age of 28 days $(\mathrm{kg})$ meet the minimum requirements of class I and elite class.

Significant difference between groups of animals of categories "high operational value" and "low operational value" is established by the following indicators: "life expectancy, months." (29.9 months, $t d=13.71)$, "duration of breeding use, months." (29.6 months, $t d=14.50)$, "obtained farrowings" ( 5.7 farrowings, $t d=14.50)$, "total piglets were obtained, heads" (70.5 heads, td $=13.85$ ), "obtained live piglets, heads" (67.7 heads, $t d=20.83$ ), "multiplicity, heads" ( 3.3 goals, $t d=10.31$ ), "nest mass at the time of weaning at the age of 28 days $(6.5 \mathrm{~kg}$, $\mathrm{td}=2.55)$. Maximum indicators "preservation, \%", "duration of the between farrowing period, days" and "number of days per farrowing" was found in sows of the category "low operational value".

Coefficients of phenotypic consolidation $\left(\mathrm{K}_{1}, \mathrm{~K}_{2}\right)$ of signs of reproductive qualities in sows of different operational value ranged from -0.785 to +0.856 .

The maximum increase in additional products on the indicator "nest mass at the time of weaning at the age of 28 days, $\mathrm{kg}^{\text {" was }}$ obtained from sows of the category "high operational value" - 6.03\%. In the conditions of breeding plants and breeders, as well as industrial complexes, we propose to conduct a systematic assessment of sows of the main herd on the indicators of the level of adaptation and reproductive qualities. The selection of repair pigs should be carried out from animals of the category "high 
operational value" and taking into account the indicators of their own productivity and reproductive qualities in accordance with the requirements of the Instructions for grading pigs.

\section{References}

Bazhov, G. M., \& Komlatskiy, V. I. (1989). Biotekhnologiya intensivnogo svinovodstva. M.: Rosagropromizdat (in Russian).

Berezovsky, M. D., \& Vashchenko P. A. (2015). Varianty poyednan riznykh henotypiv svyney v systemi hibrydyzatsiyi. Svynarstvo: mizhvidomchyy tematychnyy naukovyy zbirnyk, 67, 38-43 (in Ukrainian).

Gutyj, B., Leskiv, K., Shcherbatyy, A., Pritsak, V., Fedorovych, V., Fedorovych, O., Rusyn, V., \& Kolomiiets, I. (2017). The influence of Metisevit on biochemical and morphological indicators of blood of piglets under nitrate loading. Regulatory Mechanisms in Biosystems, 8(3), 427-432. doi: 10.15421/021766

Herasymov, V. I., Tsytsyurs'kyy, L. M., \& Zasukha, Y. V. (2003). Svynarstvo i tekhnolohiya vyrobnytstva svynyny. KH. Espada (in Ukrainian).

Hryshyna, L. P., \& Fesenko, O. H. (2015). Efektyvnist vykorystannya spetsializovanoho typu svyney za skhreshchuvannya ta hibrydyzatsiyi. Visnyk ahrarnoyi nauky Prychornomorya, 4(2), 40-47 (in Ukrainian).

Kabanov, V. (2009). Biologicheskiye osnovy povysheniya intensivnosti svinovodstva. Svinarstvo, 2, 27-28 (in Russian).

Khalak, V., Gutyj, B., Bordun, O., Ilchenko, M., \& Horchanok, A. (2020). Effect of blood serum enzymes on meat qualities of piglet productivity. Ukrainian Journal of Ecology, 10(1), 158-161. doi: 10.15421/2020_25.

Khalak, V., Gutyj, B., Bordun, O., Horchanok, A., Ilchenko, M., Smyslov, S., Kuzmenko, O., Lytvyshchenko, L. (2020). Development and reproductive qualities of sows of different breeds: innovative and traditional methods of assessment. Ukrainian Journal of Ecology, 10(2), 356-360. doi: 10.15421/2020_109

Kodak, O. V. (2010). Vplyv velychyny selektsiynykh indeksiv remontnoho molodnyaku svyney na yikh podal'shu vidtvoryuval'nu zdatnist'. Visnyk Poltavs'koyi derzhavnoyi ahrarnoyi akademiyi, 1, 208-210 (in Ukrainian).

Koryazhnov, Ye. V. (1985). Spravochnik po promyshlennomu proizvodstvu svininy. Moscow. Rossel'khokhizdat (in Russian).

Kozyr, V., Khalak, V., \& Povod, M. (2019). DNA-type results swine for MS4R-gene and its association with productivity. Agrolife: Scientific journal. University of Agronomic Sciences and Veterinari Medicine of Bucharest, 8(1), 128-133.

Lakin G. F. (1990). Biometriya. Moscow. Vysshaya shkola (in Russian).

Magomedaliev, I.M., Nekrasov, R.V., Chabaev, M.G., Dzhavakhiya, V.V., Glagoleva, E.V., Kartashov, M.I., Durnikin, D.A., \& Matsyura, A.V. (2019). Use of different concentrations of enzymesporin probiotic in feeding of growing young pigs. Ukrainian Journal of Ecology, 9, 704-708. Doi: 10.15421/2019_813.

Martyshuk, T. V., Gutyj, B. V., Zhelavskyi, M. M., Midyk. S. V., Fedorchenko, A. M., Todoriuk, V. B., Mikhaylova, O. A. (2017). Sovremennyye aspekty yevropeyskogo svinovodstva: tendentsii, problemy i perspektivy. Biologiya $\vee$ sel'skom khozyaystve, 4(17), 13-24 (in Russian).

Nahirniak, T. B., Kisera, Ya. V., Sus, H. V., Chemerys, V. A., Levkivska, N. D., \& Iglitskej, I. I. (2020). Effect of Butaselmevit-Plus on the immune system of piglets during and after weaning. Ukrainian Journal of Ecology, 10(2), 347-352. doi: 10.15421/2020_106

Polupan, Yu. P. (1996). Otsenka stepeni fenotipicheskoy konsolidatsii genealogicheskikh grupp zhivotnykh. Zootekhniya, 10, 1315 (in Russian).

Rybalko, V. P. (2015). Sostoyaniye svinovodstva Ukrainy i perspektivy yego razvitiya Nauchnyy faktor v strategii innovatsionnogo razvitiya svinovodstva: sb. mater. XXII Mezhdunar. nauch.-prakt. konf. (9-11 September 2015). Grodno. GGAU, 17-21 (in Russian).

Tserenyuk, O. M., Khvatov, T. A., \& Stryzhak, O. M. (2010). Efektyvnist selektsiynykh i otsinochnykh inhdeksiv materyns'koyi produktyvnosti svyney. NTB Instytutu tvarynnytstva NAAN. Kharkiv, 102, 173-183 (in Ukrainian).

Usenko, S. O., Shostya, A. M., Rokotyans'ka, V. O., \& Bereznyts'kyy, V. I. (2019). Patent Ukrayiny 133103. Kyiv. Derzhavne patentne vidomstvo Ukrainy (in Ukrainian).

Voloshchuk, V. M. (2014). Stan i perspektyvy rozvytku haluzi svynarstva. Visnyk ahrarnoyi nauky, 2, 17-20 (in Ukrainian).

\section{Citation:}

Khalak, V., Gutyj, B., Bordun, O., Horchanok, A., Ilchenko, M., Smyslov, S., Lytvyshchenko, L., Kuzmenko, L. (2020). Large White breed sows. Ukrainian Journal of Ecology, 10(4), 122-126.

\begin{tabular}{|l|l}
$(\mathrm{cc}) \mathrm{EY}$ \\
$\mathrm{EY}$
\end{tabular} 